\title{
Multiproxy evidence of the Neoglacial expansion of Atlantic Water to eastern Svalbard
}

\author{
Joanna Pawłowska ${ }^{1}$, Magdalena Łącka ${ }^{1}$, Małgorzata Kucharska ${ }^{1}$, Jan Pawlowski ${ }^{1,2}$, and Marek Zajączkowski ${ }^{1}$ \\ ${ }^{1}$ Institute of Oceanology, Polish Academy of Sciences, Sopot, 81-712, Poland \\ ${ }^{2}$ Department of Genetics and Evolution, University of Geneva, Geneva, CH 1211, Switzerland
}

Correspondence: Joanna Pawłowska (pawlowska@iopan.pl)

Received: 12 February 2019 - Discussion started: 20 February 2019

Revised: 31 January 2020 - Accepted: 5 February 2020 - Published: 10 March 2020

\begin{abstract}
The main goal of this study is to reconstruct the paleoceanographic development of Storfjorden during the Neoglacial ( $\sim 4 \mathrm{cal} \mathrm{kaBP})$. Storfjorden is one of the most important brine factories in the European Arctic and is responsible for deepwater production. Moreover, it is a climate-sensitive area influenced by two contrasting water masses: warm and saline Atlantic Water (AW) and cold and fresh Arctic Water (ArW). Herein, a multiproxy approach was applied to provide evidence for existing interactions between the inflow of AW and sea ice coverage, which are the major drivers of environmental changes in Storfjorden. The sedimentary and microfossil records indicate that a major reorganization of oceanographic conditions in Storfjorden occurred at $\sim 2.7 \mathrm{cal} \mathrm{kaBP}$. The cold conditions and the less pronounced presence of AW in Storfjorden during the early phase of the Neoglacial were the prerequisite conditions for the formation of extensive sea ice cover. The period after $\sim 2.7 \mathrm{cal} \mathrm{kaBP}$ was characterized by alternating short-term cooling and warming intervals. Warming was associated with pulsed inflows of AW and sea ice melting that stimulated phytoplankton blooms and organic matter supply to the bottom. The cold phases were characterized by heavy and densely packed sea ice, resulting in decreased productivity. The ancient environmental DNA (aDNA) records of foraminifera and diatoms support the occurrence of the major pulses of $\mathrm{AW}(\sim 2.3$ and $\sim 1.7 \mathrm{cal} \mathrm{ka} \mathrm{BP})$ and the variations in sea ice cover. The episodes of enhanced AW inflow were marked by an increase in the percentage of DNA sequences of monothalamous foraminifera associated with the presence of fresh phytodetritus. Cold and less productive intervals were marked by an increased proportion of monothalamous taxa known only from environmental sequencing.
\end{abstract}

The diatom aDNA record indicates that primary production was continuous during the Neoglacial, regardless of the sea ice conditions. However, the colder periods were characterized by the presence of diatom taxa associated with sea ice, whereas the present-day diatom assemblage is dominated by open-water taxa.

\section{Introduction}

The northward flow of Atlantic Water (AW) is one of the major contributors of heat to the Arctic Ocean (Polyakov et al., 2017). Recent oceanographic data indicate a warming trend due to an increased inflow of AW towards the Arctic Ocean (Rudels et al., 2015, Polyakov et al., 2017). AW has been present along the western margin of Svalbard for at least the last 12000 years (e.g., Werner et al., 2011; Rasmussen et al., 2014). One of the major intrusions of AW occurred during the early Holocene (10.8-6.8 cal ka BP). A distinct cooling and freshening of the west Spitsbergen shelf bottom-water masses occurred during the middle to late Holocene (6.8-1 cal ka BP) and were accompanied by glacier readvances in Svalbard, leading to the present-day conditions (Ślubowska-Woldengen et al., 2007; Telesiński et al., 2018). The paleoceanographic conditions in the Svalbard margins correlate closely with the sea surface temperature (SST) variations in the Nordic Seas and confirm that the Svalbard area is highly sensitive to fluctuations in the inflow of AW (Ślubowska-Woldengen et al., 2007; Werner et al., 2013). Conversely, until the 1990s eastern Svalbard was recognized as an area exclusively influenced by the East Spitsbergen Current (ESC), which carries cold, less saline 
Arctic Water (ArW) from the Barents Sea (e.g., Quadfasel et al., 1988; Piechura, 1996). However, recent studies have revealed that the oceanography of the area is much more complicated (e.g., Skogseth et al., 2007; Geyer et al., 2010). Oceanographic data obtained from conductivity-temperature sensors attached to Delphinapterus leucas show a substantial contribution of AW to Storfjorden, east Spitsbergen (Lydersen et al., 2002). Recently, Hansen et al. (2011) suggested the presence of AW in Storfjorden during the early Holocene warming (11-6.8 cal kaBP), which was further confirmed by the foraminiferal and sedimentary records of Łącka et al. (2015).

The latter part of the Holocene, the so-called Neoglacial cooling $(\sim 4 \mathrm{cal} \mathrm{kaBP})$, in the European Arctic is characterized by decreased summer insolation at northern latitudes (Berger, 1978) that correlates with a decline in summer SST (e.g., Andersen et al., 2004; Risebrobakken et al., 2010; Rasmussen et al., 2014; Ivanova et al., 2019). The cooling of the surface waters and the limited AW inflow towards the Nordic Seas led to the formation of an extended sea ice cover in the west Spitsbergen margin (Müller et al., 2012). In addition, the southwestern and eastern shelf of Spitsbergen experienced a strengthening of the East Spitsbergen Current and/or the Jan Mayen Current, leading to an intensification of ArW inflow and the formation of extensive sea ice cover (e.g., Sarnthein et al., 2003; Berben et al., 2014). Therefore, the Neoglacial is usually considered a generally cold period (e.g., Consolaro et al., 2018). However, the records from Storfjorden and the Barents Sea suggest that the Neoglacial was a period of variable oceanographic conditions with strong temperature and salinity gradients (Martrat et al., 2003; Risebrobakken et al., 2010; Sarnthein et al., 2003; Łącka et al., 2015, 2019). In addition, there is evidence of episodic intensifications of the warm AW inflow towards western Svalbard at that time (e.g., Rasmussen et al., 2012).

According to Nilsen et al. (2008), the critical parameter controlling the fjord-shelf exchange is the density difference between the fjord water masses and the AW. The local winter ice production and the formation of brine-enriched waters determine the density of local water masses, which is a key factor that enables AW to penetrate into fjords during the spring and summer. Moreover, the production of brineenriched waters and the associated deepwater overflow are key contributors to large-scale ocean circulation (Killworth, 1983). In this respect, Storfjorden is especially important because it is one of the few areas where brine-enriched waters have been frequently observed (Haarpainter et al., 2001). In recent decades, reduced brine formation has occurred during the periods with the most intensive AW advection to Storfjorden and less sea ice formation in the Barents Sea, while intense brine formation reestablishes during periods of recurrent cooling (Årthun et al., 2011; Rasmussen and Thomsen, 2014).

The aim of this study is to reconstruct the paleoceanographic development of Storfjorden during the Neoglacial at multicentennial resolution. We assumed that the periodic intensification of the AW inflow to the west Spitsbergen shelf during the Neoglacial also resulted in the appearance of AW in eastern Spitsbergen, similar to the conditions in the early Holocene (e.g., Łacka et al., 2015), affecting the density and extent of sea ice cover in the area. A multiproxy approach comprising sedimentary, microfossil and molecular records was applied to provide evidence for the interactions between the inflow of AW and sea ice coverage in Storfjorden. The ancient environmental DNA (aDNA) analysis targeted diatoms and nonfossilized monothalamous foraminifera. Both of these groups are hardly preserved in fossil records from the Svalbard fjords (Pawłowska et al., 2014) and shelf areas (Zimmermann et al., 2019, and references therein). Recent studies have demonstrated that the analysis of genetic material obtained directly from environmental samples (so-called environmental DNA) is an efficient method for performing biodiversity surveys across time and space (Thomsen and Willerslev, 2015). The content of environmental DNA samples may be analyzed by DNA metabarcoding, which consists of high-throughput sequencing of taxonomically informative DNA fragments called metabarcodes. The identification of short, species-specific DNA fragments (so-called "barcodes") allows us to obtain species-level assignments of modern and ancient DNA sequences (Herbert et al., 2003). The further demonstration that DNA can be preserved in the environment across geological timescales opened new avenues for paleoclimatic and paleoceanographic studies. Recent studies have demonstrated the preservation of DNA in marine sediments for tens to hundreds of thousands of years. An aDNA approach was successfully applied to trace the Holocene history of dinoflagellates, haptophytes (e.g., Coolen et al., 2009, 2013; Boere et al., 2009) and foraminifera in deep-sea (Lejzerowicz et al., 2013) and coastal areas (Pawłowska et al., 2014, 2016). The study of Pawłowska et al. (2016) was the first attempt to utilize foraminiferal aDNA as a paleoenvironmental proxy. This study supported the existence of extremely diverse foraminiferal assemblages. The richness of the foraminiferal community revealed by the molecular record was much higher than that in the fossil record (Pawłowska et al., 2014), mainly due to the detection of nonfossilized monothalamous taxa. The molecular data correlated well with environmental changes and revealed even small changes that were not clearly indicated by other proxy records. The combination of aDNA studies with the analysis of microfossils and sedimentary proxies provides a powerful means to reconstruct past environments more comprehensively.

\section{Study area}

Storfjorden is located in southeastern Svalbard between the islands of Spitsbergen, Edgeøya and Barentsøya (Fig. 1). 
(a)

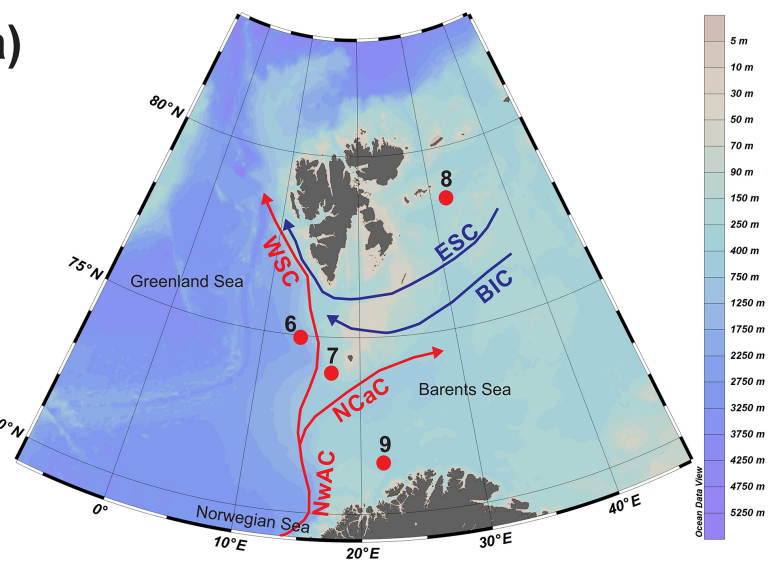

(b)
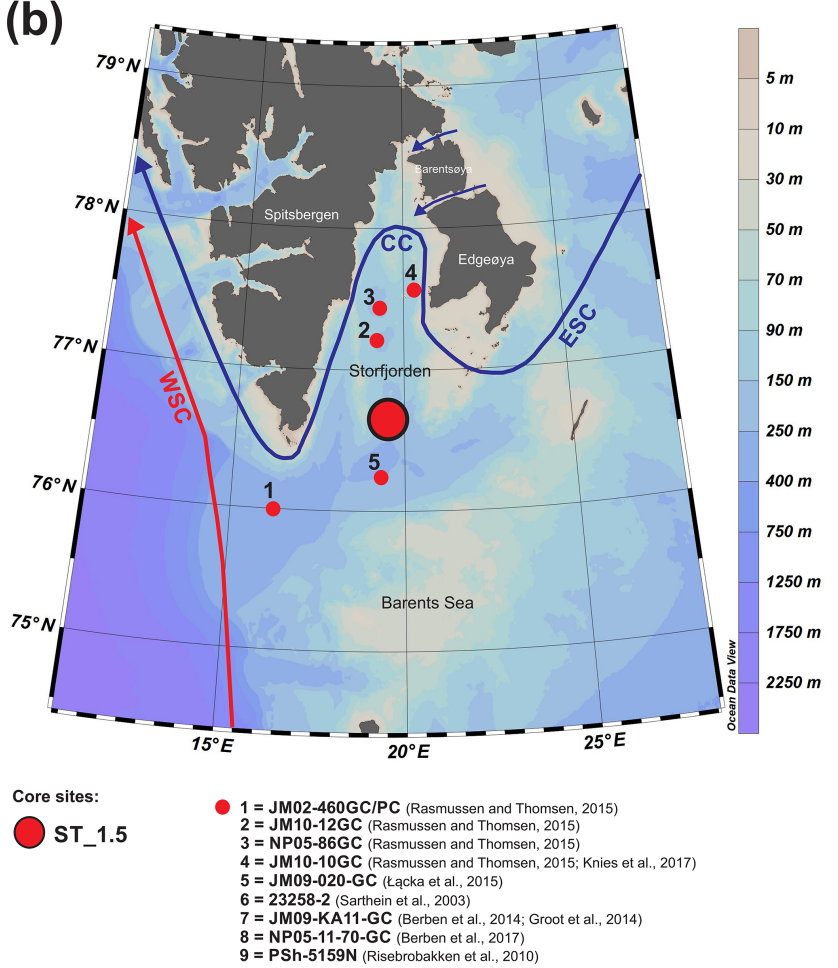

Figure 1. The modern oceanography of the study area (a) and the location of the studied core ST_1.5 (b) and the other cores discussed in this paper $(\mathbf{a}, \mathbf{b})$. Abbreviations of main surface currents: WSC - West Spitsbergen Current, NwAC - Norwegian Atlantic Current, $\mathrm{NCaC}$ - North Cape Current, ESC - East Spitsbergen Current, BIC - Bear Island Current, CC - coastal current.

Storfjorden is $\sim 190 \mathrm{~km}$ long and its main basin is $\sim 190 \mathrm{~m}$ deep. Two narrow and shallow passages (Heleysundet and Freemansundet) connect northern Storfjorden to the Barents Sea. To the south, a $120 \mathrm{~m}$ deep sill separates the main basin from Storfjordrenna. Storfjordrenna is $245 \mathrm{~m}$ long, with a depth varying from 150 to $420 \mathrm{~m}$.

The water masses in Storfjorden are composed primarily of exogenous Atlantic and Arctic waters as well as mixed waters that have formed locally. The Atlantic Water is transported northwards by the Norwegian Atlantic Current (NwAC), which branches off in the Barents Sea into the West Spitsbergen Current and North Cape Current (Loeng, 1991; Blindheim and Østerhus, 2005) (Fig. 1a). In addition to AW, cold and less saline Arctic Water (ArW) is transported to the Barents Sea via the East Spitsbergen Current and Bear Island Current (Hopkins, 1991) (Fig. 1a). Arctic Water (ArW) from the Arctic Ocean and the Barents Sea enters Storfjorden via two passages to the northeast and continues along the inner shelf of Svalbard as a coastal current (Fig. 1b). AW is characterized by temperatures $>3{ }^{\circ} \mathrm{C}$ and salinity $>34.95$, while the temperature and salinity of $\mathrm{ArW}$ are $<0^{\circ} \mathrm{C}$ and 34.3-34.8, respectively. The presence of locally formed water masses is a result of the interactions between AW, ArW and meltwater. Skogseth et al. (2005) listed six local water masses: meltwater (MW), polar front water (PW), east Spitsbergen water (ESW), brine-enriched shelf water (BSW), Storfjorden surface water (SSW) and modified Atlantic Water (MAW). BSW is formed due to the release of large amounts of brine during polynya events and the intensive formation of sea ice (Haarpainter et al., 2001; Skogseth et al., 2004, 2005) and is characterized by salinities exceeding 34.8 and temperatures below $-1.5^{\circ} \mathrm{C}$ (Skogseth et al., 2005).

The sedimentary environment in Storfjorden is classified as a low-energy, high-accumulation environment, which is characteristic of inner fjords. The area is sheltered from along-shelf bottom currents and is affected by high terrigenous inputs; therefore, deposition prevails over sediment removal by bottom currents (Winklemann and Knies, 2005). The primary productivity is high and strongly depends on the sea ice formation as well as the seasonal duration of the marginal ice zone (Winkelman and Knies, 2005).

\section{Materials and methods}

\subsection{Marine sediment core}

The $55 \mathrm{~cm}$ long sediment core ST_1.5 was taken with a gravity corer in Storfjorden retrieved with the R/V Oceania in August 2014. The sampling station was located at $76^{\circ} 53,181^{\prime} \mathrm{N}$ and $19^{\circ} 27,559^{\prime} \mathrm{E}$ at a depth of $153 \mathrm{~m}$ (Fig. 1). The salinity and temperature of the water column at the coring station were measured with a mini-CTD Sensordata SD 204 at intervals of $1 \mathrm{~s}$ (Fig. 2). The core was stored at $4{ }^{\circ} \mathrm{C}$ and shipped to the Institute of Oceanology PAS for further analyses.

In the laboratory, the core was extruded and cut into $1 \mathrm{~cm}$ slices. During cutting, sterile subsamples for ancient DNA (aDNA) analyses were taken at $4 \mathrm{~cm}$ intervals. To avoid external and/or cross-contamination the thin layers of sediment that were in contact with underlying or overlying sediments were removed using a sterile spatula. Samples for aDNA analyses were kept frozen at $-20^{\circ} \mathrm{C}$. Samples for other proxy analyses were taken every $2 \mathrm{~cm}$. 
Table 1. Raw and calibrated $\mathrm{AMS}^{14} \mathrm{C}$ dates used in the age model. B stands for bivalve shells, while $\mathrm{F}$ stands for benthic foraminifera tests.

\begin{tabular}{llrrr}
\hline Core depth $(\mathrm{cm})$ & Material & Raw AMS ${ }^{14} \mathrm{C}$ & Cal. years BP $\pm 2 \sigma$ & Cal. years BP used in age model \\
\hline 2.5 & Nuculana pernula $(\mathrm{B})$ & $107.38 \pm 0.33 \mathrm{pMC}$ & - & - \\
5.5 & Yoldiella lenticula $(\mathrm{B})$ & $290 \pm 30 \mathrm{BP}$ & - & - \\
14.5 & Turritella erosa $(\mathrm{B})$ & $2020 \pm 30 \mathrm{BP}$ & $1356-1555$ & 1500 \\
43.5 & Yoldiella solituda $(\mathrm{B})$ & $3010 \pm 50 \mathrm{BP}$ & $2484-2787$ & 4700 \\
46.5 & Nonionellina labradorica $(\mathrm{F})$ & $4490 \pm 40 \mathrm{BP}$ & $4400-4701$ & 7500 \\
52.5 & Yoldiella lenticula $(\mathrm{B})$ & $7545 \pm 35 \mathrm{BP}$ & $7803-7989$ & 7890 \\
\hline
\end{tabular}

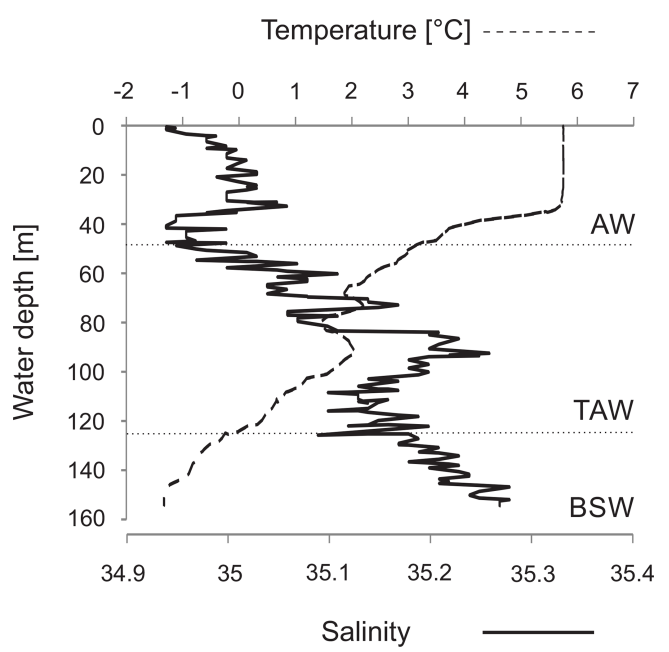

Figure 2. Temperature and salinity profile from the sampling station. Temperature is marked with a dashed line, and salinity is marked with a black line. Abbreviations: AW - Atlantic Water, TAW - transformed Atlantic Water, BSW - brine-enriched shelf water.

\subsection{Chronology}

The chronology of the marine sediment core is based on high-precision accelerator mass spectrometry (AMS) ${ }^{14} \mathrm{C}$ dating performed on five bivalve shells retrieved from the sediment layers at $2.5,5.5,14.5,43.5$ and $52.5 \mathrm{~cm}$ of core depth and on the foraminifera Nonionellina labradorica from the $46.5 \mathrm{~cm}$ core depth. The bivalve shells were identified to the highest possible taxonomic level and processed on the 1.5 SDH-Pelletron Model "Compact Carbon AMS" in the Poznań Radiocarbon Laboratory, Poznań, Poland. Dating of foraminiferal tests was performed at the National Ocean Sciences AMS (NOSAMS) laboratory in the Woods Hole Oceanographic Institution, Woods Hole, MA, USA. The dates were converted into calibrated ages using the calibration program CALIB Rev. 7.1.0 Beta (Stuiver and Reimer, 1993) and the Marine13 calibration dataset (Reimer et al., 2013). A reservoir age correction $(\Delta R)$ of $105 \pm 24$ was applied (Mangerud et al., 2006). The calibrated results are reported in units of thousand calibrated years before present (cal ka BP) (Table 1).

\subsection{Grain size analysis}

The samples for grain size analyses were freeze-dried and milled. The measurements were performed using a Mastersizer 2000 particle laser analyzer coupled to a Hydro MU device (Malvern, UK). The samples were treated with ultrasound to avoid aggregation. The raw data were analyzed using GRADISTAT v.8.0 software (Blott and Pye, 2001). The mean $0-63 \mu \mathrm{m}$ grain size $[\varphi]$ was calculated via the logarithmic method of moments. The sediment fraction $>500 \mu \mathrm{m}$ was used to reconstruct an ice-rafted debris (IRD) record. The grains were counted under a stereomicroscope, and the amount of IRD is reported as the concentration (i.e., the number of grains per gram of dry sediment) [grains $\mathrm{g}^{-1}$ ] and the flux [grains $\mathrm{cm}^{-2} \mathrm{yr}^{-1}$ ].

\subsection{Benthic foraminifera assemblages}

Prior to the analysis of benthic foraminifera, samples were wet-sieved through meshes with 500 and $100 \mu \mathrm{m}$ openings and dried at $60^{\circ} \mathrm{C}$. Samples with large quantities of tests were divided using a microsplitter. At least 300 specimens of benthic foraminifera were isolated from each sample and collected on micropaleontological slides. Benthic foraminifera specimens were counted and identified to the lowest possible taxonomic level. The quantity of foraminifera is presented as the concentration (i.e., the number of individuals per gram of dry sediment) [ind. $\mathrm{g}^{-1}$ ] and the flux [ind. $\mathrm{cm}^{-2} \mathrm{yr}^{-1}$ ]. Foraminifera species were grouped according to their ecological tolerances. Four groups of indicators were distinguished: $\mathrm{AW}$ and/or frontal zone indicators, ArW indicators, bottom current indicators, and glaciomarine species (Majewski et al., 2009). The morphologically similar species $I s$ landiella norcrossi and Islandiella helenae are reported as Islandiella spp.

\subsection{Stable isotope analysis}

Carbon and oxygen stable isotope analyses were performed on Cibicidoides lobatulus tests selected from 27 sediment layers. Approximately 10 to 12 specimens were collected from each sample and subjected to ultrasonic cleaning. The measurements were performed on a Finnigan MAT 253 mass spectrometer coupled to a Kiel IV carbonate preparation de- 
vice at the University of Florida. The resulting values are expressed in standard $\delta$ notation relative to Vienna Pee Dee Belemnite (VPDB).

\subsection{Ancient DNA analysis}

The total DNA was extracted from approximately $10 \mathrm{~g}$ of sediment using a Power Max Soil DNA extraction kit (MoBio). The foraminiferal SSU rDNA fragments containing the $37 \mathrm{f}$ hypervariable region were PCR-amplified (PCR: polymerase chain reaction) using primers tagged with unique sequences of five nucleotides appended to their $5^{\prime}$ ends (denoted by $\mathrm{Xs}$ ), namely, the foraminifera-specific forward primer s14F1 (5'-XXXXXCGGACACACTGAGGATTGACAG$\left.3^{\prime}\right)$ and the reverse primer $\mathrm{S} 15 \quad\left(5^{\prime}-\right.$ XXXXXCCTATCACATAATCATGAAAG-3'). The diatom DNA fragment located in the V4 region was amplified with the forward DIV4for (5'XXXXXXXXGCGGTAATTCCAGCTCCAATAG-

$\left.3^{\prime}\right)$ and reverse DIV4rev3 (5'-
XXXXXXXXCTCTGACAATGGAATACGAATA-3')

primers tagged with a unique combination of eight nucleotides (denoted by Xs) attached at each primer's $5^{\prime}$ end. The amplicons were purified using the High Pure PCR Cleanup Micro Kit (Roche) and quantified using a Qubit 2.0 fluorometer. Samples were pooled in equimolar quantities, and the sequence library was prepared using a TruSeq library-preparation kit (Illumina). The samples were then loaded into a MiSeq instrument for a paired-end run of $2 \times 150$ cycles (foraminifera) and $2 \times 250$ cycles (diatoms). The processing of the high-throughput sequencing (HTS) data was performed according to procedures described by Lejzerowicz et al. (2013) and Pawłowska et al. (2014). The post-sequencing data processing was performed with the use of the SLIM web app (Dufresne et al., 2019) and included demultiplexing the libraries, joining the paired-end reads, chimera removal, operational taxonomic units (OTUs) clustering and taxonomic assignment. Sequences were clustered into OTUs using the Swarm module (Mahe et al. 2014), and each OTU was assigned to the highest possible taxonomic level using vsearch (Rognes et al., 2016) against a local database and then reassigned using BLAST (Altschul et al., 1990). The results are presented in OTU-to-sample tables and transformed in terms of the number of sequences, the number of OTUs and the percentage $(\%)$ of sequences.

\section{Results}

\subsection{Chronology}

In total, six radiocarbon dates were obtained, all of which were recorded in chronological order. The uppermost layer contained modern, post-bomb carbon, indicating a post- 1960 age (Table 1). Samples from the 2.5 and $5.5 \mathrm{~cm}$ core depths

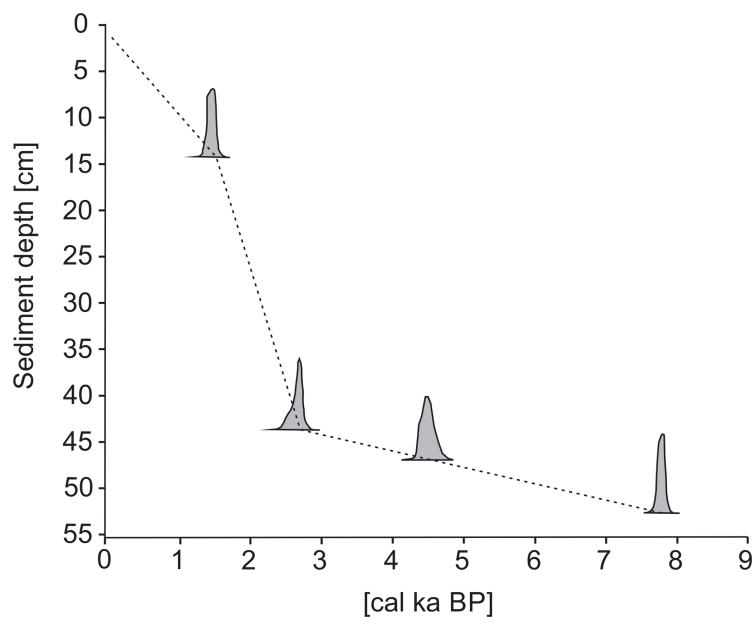

Figure 3. Age-depth model of the ST_1.5 core. The grey silhouettes show the probability distribution of calendar dates that were obtained by calibration of the individual ${ }^{14} \mathrm{C}$ dates used for the age model. The dotted line shows the age-depth model derived from a linear interpolation between the dates.

were not calibrated because they revealed ages invalid for the selected calibration curve. The age model was therefore based on the four remaining dates using a linear interpolation. The age of the bottom of the core was estimated to be approximately $\sim 7.9 \mathrm{cal} \mathrm{kaBP}$ (Fig. 3). However, the extremely low temporal resolution between $\sim 7.9$ and $\sim 4$ cal ka BP precluded making any general conclusion about that interval. Therefore, this study focuses only on the last $\sim 4$ cal ka BP (the Neoglacial).

\subsection{Sediment grain size}

The sediment was classified as medium to coarse silt throughout the core. The sediment accumulation rate (SAR) prior to $\sim 2.7 \mathrm{cal} \mathrm{kaBP}$ was $0.002 \mathrm{~cm} \mathrm{yr}^{-1}$. The approximately 10-fold increase in SAR was noted at $\sim$ $2.7 \mathrm{cal} \mathrm{ka} \mathrm{BP}$, when it increased to $0.023 \mathrm{~cm} \mathrm{yr}^{-1}$. During the last $1.5 \mathrm{cal} \mathrm{ka} \mathrm{BP,} \mathrm{SAR} \mathrm{decreased} \mathrm{to} 0.01 \mathrm{~cm} \mathrm{yr}^{-1}$ (Fig. 4). The amount of IRD was the highest prior to $\sim 2.7 \mathrm{cal} \mathrm{kaBP}$, reaching up to 83 grains $^{-1}$. After $\sim 2.7 \mathrm{cal} \mathrm{ka} \mathrm{BP,} \mathrm{the}$ amount of IRD was relatively stable and did not exceed 18 grains $\mathrm{g}^{-1}$. The IRD flux decreased slightly over time to 0.37 grains $\mathrm{g}^{-1} \mathrm{~cm}^{-1}$, except for one peak reaching 0.8 grains $\mathrm{g}^{-1} \mathrm{~cm}^{-1}$ at $\sim 2.6$ cal ka BP (Fig. 4).

The mean grain size of the $0-63 \mu \mathrm{m}$ fraction had its highest value $(5.8 \varphi)$ at $\sim 2.7 \mathrm{cal} \mathrm{ka} \mathrm{BP} \mathrm{(Fig.} \mathrm{4).} \mathrm{After} \sim 2.4 \mathrm{cal} \mathrm{ka} \mathrm{BP}$ a slight but continuous reduction in the mean $0-63 \mu \mathrm{m}$ grain size was noted. The minimum grain size $(6.23 \varphi)$ was recorded at the top of the core (Fig. 4). 


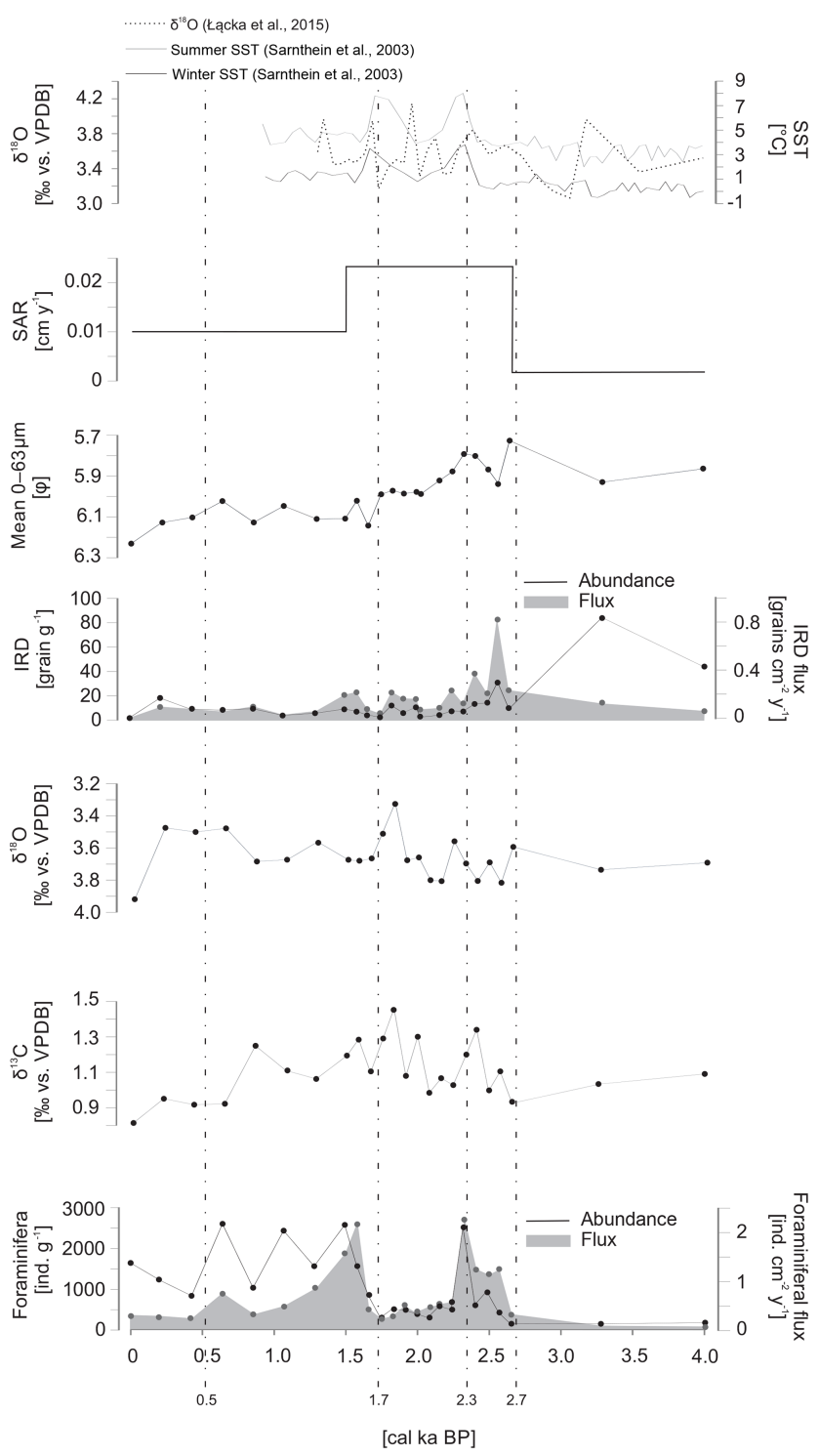

Figure 4. Sedimentological and micropaleontological data plotted versus age. The sediment accumulation rate (SAR), mean grain size of the $0-63 \mu \mathrm{m}$ fraction, ice-rafted debris (IRD) flux and number of grains per gram of sediment, oxygen $\left(\delta^{18} \mathrm{O}\right)$ and carbon $\left(\delta^{13} \mathrm{C}\right)$ stable isotopes in benthic foraminiferal tests, and the flux and abundance of foraminifera are presented.

\subsection{Stable isotopes}

The two $\delta^{18} \mathrm{O}$ data points prior to $\sim 2.7 \mathrm{cal} \mathrm{kaBP}$ recorded values of $3.55 \%$ and $3.69 \%$ vs. VPDB. Between $\sim 2.7$ and $\sim 1.5 \mathrm{cal} \mathrm{kaBP}, \delta^{18} \mathrm{O}$ showed the strongest variation, with values ranging from $3.28 \%$ to $3.77 \%$ vs. VPDB. After $\sim$ $1.5 \mathrm{cal} \mathrm{ka} \mathrm{BP}, \delta^{18} \mathrm{O}$ became slightly lighter $(3.43 \%$ o $-3.64 \%$ o vs. VPDB), except for one peak noted in the uppermost layer of the core, where $\delta^{18} \mathrm{O}$ reached $3.87 \%$ vs. VPDB (Fig. 4).

In the period prior to $\sim 2.7 \mathrm{cal} \mathrm{kaBP}$, recorded values of $\delta^{13} \mathrm{C}$ reached $0.92 \%$ and $1.12 \%$ vs. VPDB. Slightly heavier $\delta^{13} \mathrm{C}$ (up to $1.46 \%$ ovs. VPDB) was observed between $\sim 2.7$ and $\sim 1.5 \mathrm{cal} \mathrm{ka} \mathrm{BP.} \mathrm{The} \mathrm{gradual} \mathrm{decrease} \mathrm{was} \mathrm{recorded} \mathrm{from}$ $\sim 1.5 \mathrm{cal} \mathrm{kaBP}$ to the present, reaching $0.81 \%$ vs. VPDB at the top of the core (Fig. 4).

\subsection{Benthic foraminifera assemblages}

A total of 8647 fossil foraminifera specimens belonging to 47 species were identified (Supplement Fig. S1). The number of foraminifera individuals in a sample varied from 156 to 2610 ind. $\mathrm{g}^{-1}$, and the lowest abundances were observed prior to $\sim 2.7 \mathrm{cal} \mathrm{kaBP}$ (Fig. 4). A short-term decrease in foraminifera abundance was observed between 2.2 and $1.7 \mathrm{cal} \mathrm{kaBP}$, with values reaching as low as 304 ind. $\mathrm{g}^{-1}$. The abundance maxima were noted at $2.3,1.5$ and $0.6 \mathrm{kaBP}$, with values reaching 2524,2584 and 2610 ind. $\mathrm{g}^{-1}$, respectively. The foraminiferal flux was low and relatively stable throughout the core, with values that did not exceed 1 ind. $\mathrm{cm}^{-2} \mathrm{yr}^{-1}$, except for two peaks at 2.3 and $1.5 \mathrm{kaBP}$, when the flux reached 2.2 ind. $\mathrm{cm}^{-2} \mathrm{yr}^{-1}$ for both peaks (Fig. 4).

The most abundant species was Cassidulina reniforme, with densities reaching up to 900 ind. $\mathrm{g}^{-1}$. The other species that constituted the majority of the foraminiferal assemblage were Buccella frigida, Cibicidoides lobatulus, Elphidium excavatum, Islandiella spp., Melonis barleeanum and Nonionellina labradorica. The abundances of the dominant species followed a general trend, with maxima at $\sim$ $2.3 \mathrm{cal} \mathrm{kaBP}$ and after $\sim 1.7 \mathrm{cal} \mathrm{kaBP}$ and minima prior to $\sim 2.7 \mathrm{cal} \mathrm{ka} \mathrm{BP}$ and between 2.3 and $1.7 \mathrm{cal} \mathrm{ka} \mathrm{BP} \mathrm{(Fig.} \mathrm{5).}$

The foraminiferal assemblage prior to $\sim 2.7 \mathrm{cal} \mathrm{kaBP}$ was dominated by indicators of AW inflow and/or frontal zones and glaciomarine taxa (Fig. 5). The most abundant species were Nonionellina labradorica and Melonis barleeanum, as well as Cassidulina reniforme and Elphidium excavatum, which together accounted for up to $60 \%$ of the foraminiferal abundance (Fig. 5). After $\sim 2.7 \mathrm{cal} \mathrm{ka} \mathrm{BP,}$ there were $\mathrm{AW}$ and/or frontal zone indicator peaks recorded at 2.4 and $1.8 \mathrm{cal} \mathrm{kaBP}$, when the percentages increased to $33 \%$ and $28 \%$ of the total abundance, respectively. The period between $\sim 2.4$ and $\sim 1.8 \mathrm{cal} \mathrm{kaBP}$ was characterized by an increase in the percentage of sea ice indicators (B. frigida and Islandiella spp.), which accounted for up to $25 \%$ of the total foraminiferal abundance. Additionally, a short-term peak in the glaciomarine taxa, reaching up to $49 \%$ of the foraminiferal assemblage, was recorded between 2.5 and $2.1 \mathrm{cal} \mathrm{kaBP}$. Also, the overall maximum of glaciomarine species abundance was recorded between 1.7 and $0.5 \mathrm{cal} \mathrm{kaBP}$, ranging from $25 \%$ to $43 \%$ of the foraminiferal assemblage (Fig. 5). A decrease in the relative abundance of glaciomarine species was observed after $\sim 0.5 \mathrm{cal} \mathrm{kaBP}$ and was followed by an increase in the AW and/or frontal zone indicators and a single peak in the percentage of bottom current indicators, which reached $42 \%$ and $19 \%$, respectively (Fig. 5). 


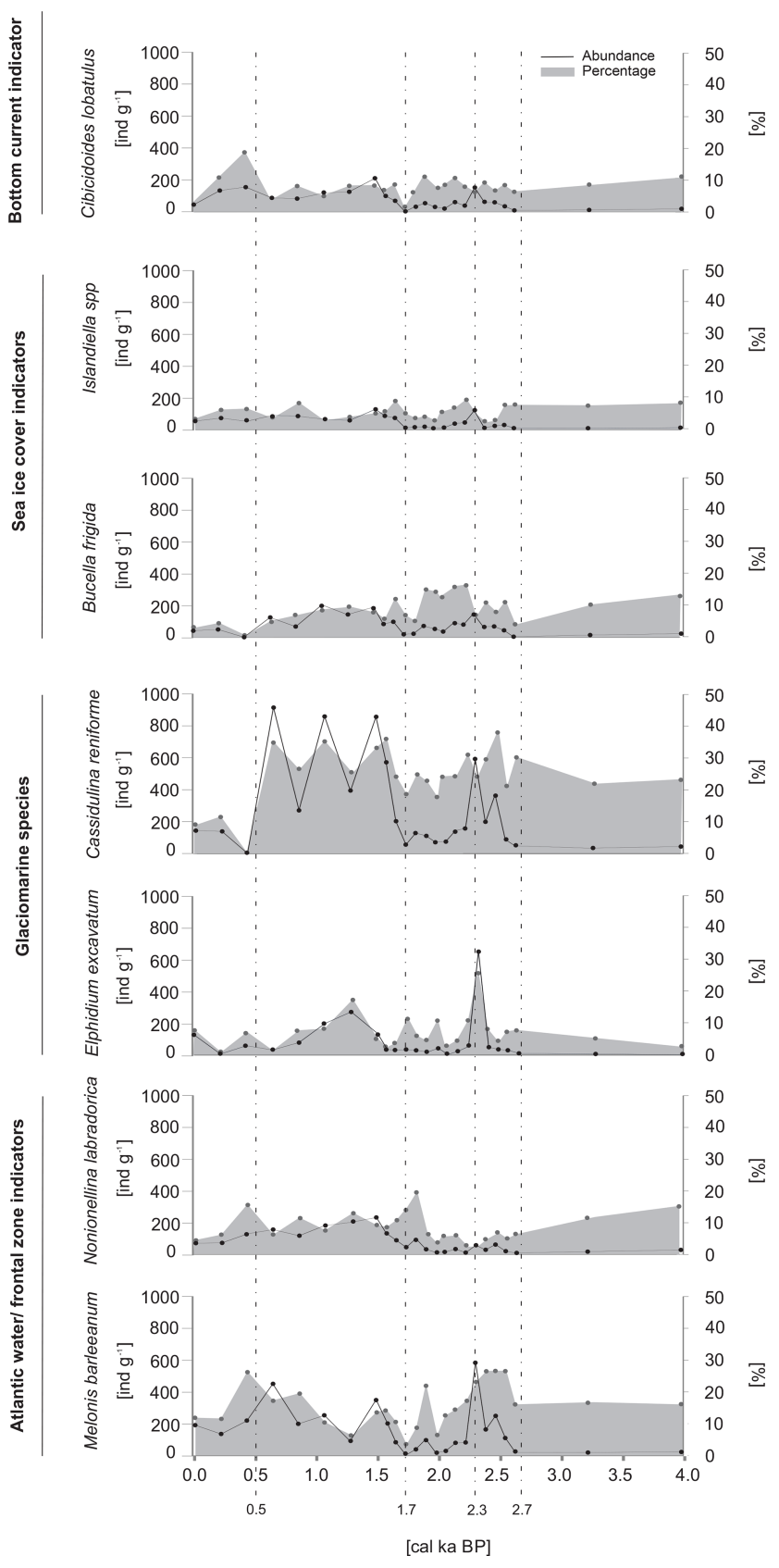

Figure 5. The absolute abundance (expressed as the number of individuals per gram of dry sediment) and the percentage of the dominant benthic foraminifera.

\subsection{Foraminiferal aDNA sequences}

A total of 1499889 foraminiferal DNA sequences were clustered into 263 OTUs, and 20 remained unassigned. The remaining OTUs were assigned to Globigerinida (5 OTUs), Robertinida (1 OTU), Rotaliida (49 OTUs), Textulariida (18 OTUs), Monothalamea (163 OTUs) and Miliolida (7 OTUs). The majority of sequences belonged to Monothalamea $(60 \%)$ and Rotaliida (31\%) (Fig. S2). Herein, we focus on Monothalamea, which is the dominant component of the foraminiferal aDNA record.

The most important components of the monothalamous assemblage were Micrometula sp., Cylindrogullmia sp., Hippocrepinella hirudinea, Ovammina sp., Nemogullmia sp., Tinogullmia sp., Cedhagenia saltatus, undetermined allogromiids belonging to clades A and Y (herein called "allogromiids"), and sequences belonging to taxa known exclusively from environmental sequencing (herein called "environmental clades"). Herein, the term "allogromiid" refers to monothalamous foraminifera with organic or predominantly organic test walls (Gooday, 2002). Morphological and molecular evidence indicates that "allogromiids" are not a coherent taxonomic group but are scattered between several monothalamous clades (Pawlowski et al., 2002). "Clade" refers to phylogenetic clades defined by molecular data. The clade is traditionally defined as a group of organisms that includes a common ancestor and all the descendants. The sequences belonging to allogromiids were present throughout the core, accounting for $16 \%-31.7 \%$ of all the foraminiferal sequences. The exceptions were the intervals from $\sim 4.0$ to $2.4 \mathrm{cal} \mathrm{kaBP}$ and $\sim 1.7 \mathrm{cal} \mathrm{ka} \mathrm{BP}$, when the contribution of allogromiid sequences decreased to less than $10 \%$ (Fig. 6). The majority of the allogromiids belonged to clade $\mathrm{Y}$, which made up to $100 \%$ of the allogromiid sequences. Only at 1.6-1.7 and 2.4-2.6 cal ka BP did most of the allogromiid sequences belong to clade A. Additionally, allogromiids belonging to clade I were noted at $\sim 2.4 \mathrm{cal} \mathrm{kaBP}$, when they made up $0.88 \%$ of allogromiid sequences (Fig. 7).

The periods prior to $\sim 2.4$ and $\sim 1.7 \mathrm{cal} \mathrm{kaBP}$ were marked by the disappearance of sequences belonging to $C$. saltatus, Nemogullmia sp. and the environmental clades, followed by an increase in the percentages of sequences belonging to Micrometula sp., Ovammina sp., Tinogullmia sp., Shepheardella sp. and Cylindrogullmia sp. (Fig. 6).

\subsection{Diatom aDNA sequences}

A total of 824697 diatom DNA sequences were clustered into 221 OTUs (Fig. S3). The most abundantly sequenced diatom taxa were Thalassiosira spp, which made up $61.1 \%$ of diatom sequences. Other abundantly sequenced taxa were Chaetoceros sp. and T. antarctica, which made up $8.5 \%$ and $11.5 \%$ of sequences, respectively. The sequences of Thalassiosira sp. were most abundant between $\sim 2.2$ and $\sim 1.9$ cal kaBP, accounting for up to $85 \%$ of all diatom sequences. The lowest percentage (14\%) of Thalassiosira sp. was recorded at $\sim 0.4 \mathrm{cal} \mathrm{ka} \mathrm{BP.} \mathrm{Sequences} \mathrm{assigned} \mathrm{to}$ T. antarctica were recorded throughout the core, and their percentages were the highest at $\sim 3.3$ and $\sim 2.6 \mathrm{cal} \mathrm{kaBP}$, reaching up to $13 \%$ and $19 \%$, respectively (Fig. 8). Sequences of $T$. hispida were also noted throughout the core and constituted $4.7 \%$ of diatom sequences in the uppermost layer. In the remaining samples, $T$. hispida sequences did not exceed $1 \%$. The percentage of sequences of Chaetoceros sp. 

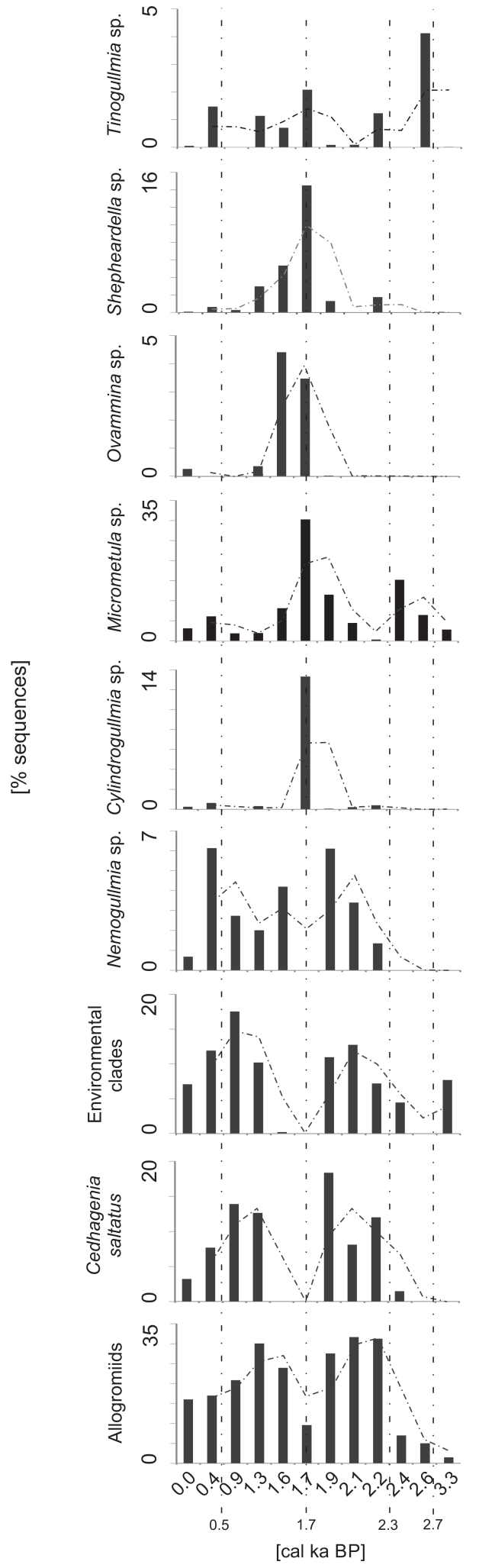

Figure 6. The dominant components of the monothalamous assemblages. The abundance is expressed as the percentage of the monothalamous sequences, and the most abundantly sequenced taxa are presented. The trend (two-point average) is indicated with a dashed line.

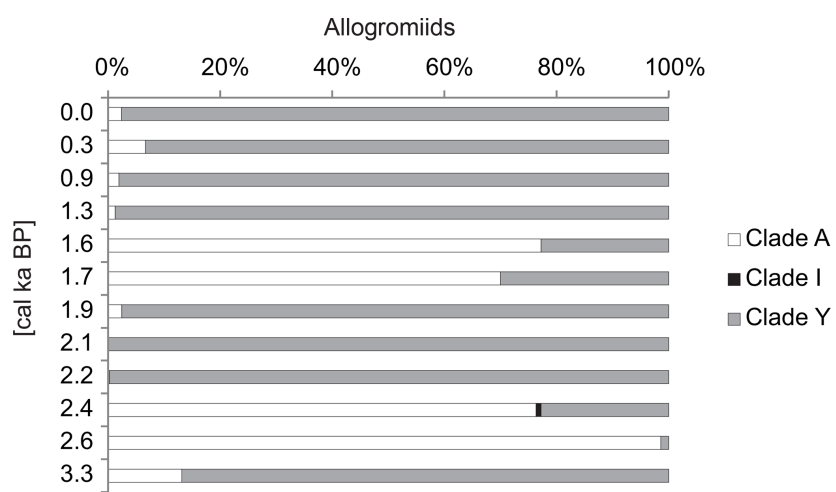

Figure 7. The percentage share of certain clades in the allogromiid sequences.

decreased downcore, from $76 \%$ at the surface to less than $1 \%$ at the bottom of the core (Fig. 8). Navicula sp. constituted an important part of the diatom assemblage at $\sim 3.3$ and $\sim 1.9$ cal ka BP, accounting for up to $25.5 \%$ and $10 \%$ of all diatom sequences, respectively. In the remaining samples, the abundance of Navicula sp. did not exceed $5 \%$ (Fig. 8).

\section{Discussion}

The ST_1.5 age model is based on the linear interpolation between the four $\mathrm{AMS}^{14} \mathrm{C}$ dates; thus, the age control of the core should be treated with caution. However, the timing of major environmental changes revealed by the ST_1.5 multiproxy record is in agreement with other records from the region (e.g., Sarnthein et al., 2003; Risebrobakken et al., 2010; Berben et al. 2017). Moreover, the major pulses of AW that were recorded $\sim 2.3$ and 1.7 cal kaBP correlated well with winter and summer SST maxima recorded in the 23258-2 core (Sarnthein et al., 2003).

\subsection{The period from 4 to $2.7 \mathrm{cal} \mathrm{ka} \mathrm{BP}$}

Prior to $\sim 2.7$ cal ka BP, the ST_1.5 sedimentary record displayed relatively higher IRD delivery and a relatively lower 0-63 $\mu \mathrm{m}$ sediment fraction than in the following period (Fig. 4). These results are in agreement with the record from Storfjordrenna (Łącka et al., 2015), where peaks in IRD were noted during the Neoglacial and were attributed to increased iceberg rafting due to fluctuations in the glacial fronts (e.g., Forwick et al., 2010).The coarser 0-63 $\mu \mathrm{m}$ fraction may suggest the winnowing of fine-grained sediment; however, foraminiferal fauna showed no clear response to sediment removal.

The foraminiferal flux and abundance prior to $2.7 \mathrm{cal} k \mathrm{kBP}$ reached their lowest values (Fig. 4). Previous studies reported a decrease in the concentration of benthic foraminifera in Storfjorden at that time, which was attributed to the presence of extensive ice cover (Rasmussen and Thomsen, 2015; Knies et al., 2017). The dominant 


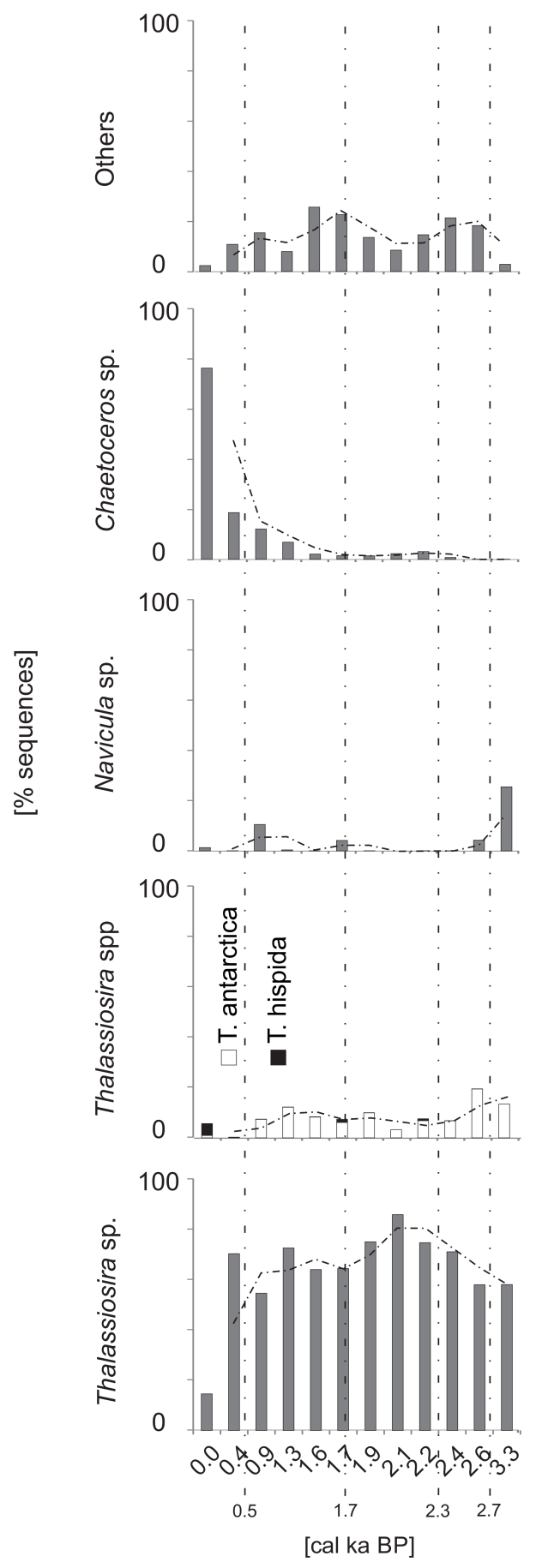

Figure 8. The percentage of sequences of dominant diatom taxa vs. time. The trend (two-point average) is indicated with a dashed line.

components of the ST_1.5 foraminiferal assemblage were $C$. reniforme and M. barleeanum (Fig. 5). The presence of $C$. reniforme and $M$. barleeanum is associated with cooled and salty AW (e.g., Hald and Steinsund, 1996; Jernas et al., 2013). Moreover, these species are also associated with the presence of phytodetritus, which may be related to the delivery of fresh organic matter observed in frontal zones and/or near the sea ice edge (Jennings et al., 2004). The presence of sea ice may also be indicated by the relatively light foraminiferal $\delta^{13} \mathrm{C}$ (Fig. 4), as well as the highest percentage of the sea ice species Thalassiosira antarctica (see Ikävalko, 2004; Fig. 8). However, the low sampling resolution during that period precluded us from making a general conclusion, and the latter assumptions should be confirmed by further studies.

\subsection{The period from 2.7 to 0.5 cal ka BP: episodes of AW inflow at $\sim 2.3$ and 1.7 cal ka BP}

After $\sim 2.7 \mathrm{cal} \mathrm{ka}$ BP, the increase in SAR was followed by a decrease in the mean grain size of the $0-63 \mu \mathrm{m}$ fraction and in the IRD delivery (Fig. 4). The 10-fold increase in SAR most likely resulted from the intensive supply of turbid meltwater from advancing glaciers and the consequent intensive sedimentation. Moreover, the accumulation of fine sediment may also be enhanced by the slowdown of the bottom currents, indicated by the finer $0-63 \mu \mathrm{m}$ sediment fraction (Fig. 4). On the other hand, a decrease in IRD delivery may suggest that central Storfjorden was not impacted by iceberg rafting at that time. In contrast, Rasmussen and Thomsen (2015) suggested glacial advance, followed by intensive ice rafting and meltwater delivery to Storfjorden at that time. According to Knies et al. (2017), inner Storfjorden was covered by densely packed sea ice between $\sim 2.8$ and $0.5 \mathrm{cal} \mathrm{ka}$ BP. Therefore, the decreasing IRD in the ST_1.5 core may result from the presence of a sea ice cover that reduced iceberg rafting, while the majority of coarse-grained material settled in the proximity to the glacial fronts. Similar conclusions have been stated by Forwick and Vorren (2009) and Forwick et al. (2010), who assumed that the enhanced formation of sea ice along the west Spitsbergen coast trapped icebergs inside the Isfjorden system.

The foraminiferal fauna in central Storfjorden revealed more than a 10-fold increase in flux and abundance, followed by short-term fluctuations after $\sim 2.7 \mathrm{cal} \mathrm{ka} \mathrm{BP} \mathrm{(Fig.} \mathrm{4).} \mathrm{The}$ latter may suggest favorable conditions for foraminiferal growth. The major peaks in the total foraminiferal abundance (Fig. 4), followed by the peaks in the percentage of AW foraminiferal indicators (Fig. 5), were noted at $\sim 2.3$ and $\sim 1.7$ cal ka BP. These peaks were associated with the occurrence of sequences of T. hispida (Fig. 8), a diatom species characteristic of subpolar and temperate regions (Katsuki et al., 2009). The timing of the changes described above is in accordance with the findings of Sarntheim et al. (2003), who reported two intervals of a remarkably warmer sea surface on the western continental margin of the Barents Sea at $\sim 2.2$ and $\sim 1.6 \mathrm{cal} \mathrm{ka} \mathrm{BP}$, which was attributed to short-term pulses of warm AW advection. Other records also indicated AW inflow to the western and northern Barents Sea as well as to the western Spitsbergen continental margin during the middle to late Holocene (e.g., Risebrobakken et al., 2010; 
Müller et al., 2012; Groot et al., 2014; Berben et al., 2014, 2017). During the mid-Holocene, AW inflow to the Barents Sea was relatively stable. The environmental conditions became more unstable in the late Holocene, with periodic cooling of surface waters, the presence of AW and/or chilled AW near the bottom, and more extensive seasonal sea ice cover (Risebrobakken et al., 2010; Berben et al., 2014; Groot et al. 2014). The timing of these changes differed between the study settings: in the western Barents Sea, it was $\sim 1.1$ to 1.5 cal ka BP (Berben et al., 2014; Groot et al., 2014), while in the southwestern Barents Sea, the change in environmental conditions was recorded at $\sim 2.5 \mathrm{cal}$ ka BP (Risebrobakken et al., 2014). In contrast, the northern Barents Sea experienced surface water cooling and more extensive sea ice cover prior to $2.7 \mathrm{cal} \mathrm{kaBP}$. The increasing influence of $\mathrm{AW}$ was observed after $2.7 \mathrm{cal} \mathrm{ka} \mathrm{BP}$ (Berben et al., 2017). Our foraminiferal and diatom aDNA records confirm the presence of AW intrusions in Storfjorden after $\sim 2.7 \mathrm{cal} \mathrm{ka} \mathrm{BP}$ that may have caused an episodic breakup of sea ice cover and permitted primary production as well as the development of benthic biota, including foraminifera.

The pulses of AW inflow at 2.3 and $1.7 \mathrm{cal} \mathrm{kaBP}$ were marked by the maxima of the foraminiferal flux (Fig. 4) and by peaks in the abundance of species associated with highly productive environments, such as $M$. barleeanum and N. labradorica (Fig. 5). Moreover, the presence of diatom aDNA sequences throughout the core (Fig. 8) may suggest continuous primary production. However, the responses of the benthic foraminifera assemblage to the pulses of AW at $\sim 2.3$ and $\sim 1.7 \mathrm{cal} \mathrm{kaBP}$ are slightly different. The dominant components of the foraminiferal assemblage at $\sim 2.3 \mathrm{cal} \mathrm{ka}$ BP were $M$. barleeanum and $E$. excavatum, while at $\sim 1.7 \mathrm{cal} \mathrm{kaBP,} N$. labradorica and $C$. reniforme were dominant (Fig. 5). The major difference in environmental conditions between these two "AW episodes" was the coarser 0-63 $\mu \mathrm{m}$ sediment fraction noted at $\sim 2.3 \mathrm{cal} \mathrm{ka} \mathrm{BP}$; this may indicate more intensive winnowing of fine sediment grains, which would have created favorable conditions for the development of opportunistic species, such as E. excavatum. In contrast, the interval between 2.3 and $1.7 \mathrm{cal} \mathrm{ka} \mathrm{BP}$ featured variable $\delta^{13} \mathrm{C}$ and $\delta^{18} \mathrm{O}$, followed by a decrease in the foraminiferal flux and abundance (Fig. 4). The foraminiferal assemblage at this time was dominated by glaciomarine and sea ice taxa (Fig. 5), which indicate more severe environmental conditions with extensive ice cover and suppressed productivity.

The alternate cooling and warming periods described above were also reflected in the aDNA record of monothalamous foraminifera. During the periods with more severe environmental conditions (i.e., time intervals of 2.21.9 and $1.3-0.4 \mathrm{cal} \mathrm{ka} \mathrm{BP}$ ), the monothalamous foraminifera were dominated by allogromiids belonging to clade $\mathrm{Y}$ (Nemogullmia sp., C. saltatus) and monothalamids belonging to so-called environmental clades (Fig. 6). A considerable portion of the allogromiid sequences in the ST_1.5 core belong to clade Y (Fig. 7), which is primarily composed of taxa known only from environmental sequencing that have previously been noted in modern sediments in the Spitsbergen fjords (Pawłowska et al., unpublished). Clade Y has also been abundantly sequenced in the coastal areas off Scotland, characterized by high levels of environmental disturbances (Pawlowski et al., 2014); this might suggest its high tolerance to environmental stress. C. saltatus was found by Gooday et al. (2011) in the Black Sea, and its occurrence in areas with high levels of pollution suggests that it is an opportunistic species with a high tolerance for environmental disturbances. In addition, so-called environmental clades are composed of monothalamous taxa known exclusively from environmental sequencing (Lecroq et al., 2011). The abovementioned taxa nearly disappeared during the episodes of enhanced AW inflow at $\sim 2.4$ and $\sim 1.7 \mathrm{cal} \mathrm{kaBP}$, and the monothalamous assemblage was dominated at that time by Micrometula sp., Ovammina sp., Shepheardella sp., Tinogullmia sp., Cylindrogullmia sp. and allogromiids belonging to clade A (Figs. 6, 7). All these taxa have recently been observed in the fjords of Svalbard and Novaya Zemlya (e.g., Gooday et al., 2005; Majewski et al., 2005; Sabbattini et al., 2007; Pawłowska et al., 2014; Korsun and Hald, 1998; Korsun et al., 1995). Cylindrogullmia and Micrometula are dependent on the presence of fresh phytodetritus (Alve, 2010). Ovammina sp. feeds on diatoms and other forms of microalgae (Goldstein and Alve, 2011). Similarly, the presence of Tinogullmia is largely controlled by the presence of organic material on the seafloor. High concentrations of Tinogullmia have been found in coastal (Cornelius and Gooday, 2004) and deep-sea regions (Gooday, 1993) within phytodetrital aggregates.

The taxa that dominated the monothalamous assemblage during warm intervals seem to be responsive to the delivery of organic matter and may flourish during phytoplankton blooms associated with the settling of organic matter (e.g., Alve, 2010; Sabbattini et al., 2012, 2013). The pulses of AW inflow may be associated with phytoplankton blooms stimulated by sea ice melting and with the organic matter supply to the bottom (see Łacka et al., 2019). The continuous aDNA record of the sea ice diatom $T$. antarctica (Fig. 8) suggests the presence of at least seasonal ice cover in the study area. On the other hand, the episodes of AW inflow were associated with the occurrence of the open-water taxa T. hispida (Fig. 8). The occurrence of sequences of both these taxa suggests the formation of ice cover during winterspring, followed by ice-free summers. A similar scenario was proposed by Berben et al. (2017), who suggested increased AW to eastern Svalbard and partial summer sea ice occurrence after $2.7 \mathrm{cal} \mathrm{ka} \mathrm{BP}$. According to the record of Łącka et al. (2019) from Storfjordrenna, the sea ice melting induced the production of brine, which may launch convective mixing and nutrient resupply from the bottom; this stimulated primary production. 
Conversely, the colder phases of the Neoglacial were characterized by heavy and densely packed sea ice, resulting in limited productivity (Knies et al., 2017). The presence of $T$. antarctica sequences and the disappearance of $T$. hispida (Fig. 8) may suggest that primary production was associated with sea ice. Furthermore, the monothalamous assemblage was less diverse and was dominated by more opportunistic taxa, which may indicate a reduced supply of organic matter to the bottom.

\subsection{The period after 0.5 cal ka BP}

Modern-like conditions were established in Storfjorden at $\sim 0.5$ cal ka BP (Knies et al., 2017). The ST_1.5 record displayed a decrease in SAR compared to the preceding period, a decreasing 0-63 $\mu \mathrm{m}$ fraction and low IRD delivery (Fig. 4), which may indicate reduced glacial impact. Moreover, the peak of heavy $\delta^{18} \mathrm{O}$ recorded on the core top (Fig. 4) may suggest the presence of AW or slightly increased salinity. Similarly, Berben et al. (2014) recorded $\delta^{18} \mathrm{O}$ values that suggested a minor increase in salinity, while foraminiferal fauna showed slightly lower salinities in the western Barents Sea at that time. The latter is in accordance with records from the Fram Strait (e.g., Werner et al., 2013) and the western Spitsbergen shelf (Cabedo-Sanz and Belt, 2016), which suggest episodes of freshening of the surface water masses associated with alternating sea ice increases and ice-free conditions in the late Holocene. Additionally, the records of Rasmussen and Thomsen (2014) and Knies et al. (2017) from Storfjorden indicated seasonally variable sea ice cover. Moreover, the majority of diatom aDNA sequences found in the ST_1.5 record after $\sim 0.5$ cal ka BP belonged to Chaetoceros sp. (Fig. 8), a taxa that is observed in surface waters and is almost entirely absent under sea ice (Różańska et al., 2008). High abundances of Chaetoceros are often associated with highly productive surface waters (Cremer, 1999). Rigual-Hernández et al. (2017) also noted an increased abundance of Chaetoceros sp. and enhanced algal productivity in Storfjorden after 2.0 cal ka BP, which was associated with the vicinity of the Arctic Front. However, the aDNA record of the monothalamous foraminifera at $\sim 0.4 \mathrm{cal} \mathrm{ka} \mathrm{BP}$ displayed relatively high percentages of taxa that dominated during the colder intervals of the Neoglacial (Fig. 6). This may be related to the recovery from the Little Ice Age (LIA) and consequently from the temporarily deteriorated environmental conditions (D'Andrea et al., 2012). However, due to the low resolution during the LIA, a detailed interpretation is not possible. Therefore, further studies are required to confirm the latter conclusion.

\subsection{Paleoceanographic implications}

Our record revealed a two-phase Neoglacial, with a major shift in environmental conditions at $\sim 2.7$ cal ka BP. According to the $\mathrm{ST}_{-} 1.5$ proxy records, the Neoglacial in Storfjor- den was not a constantly cold period, but comprised alternating short-term cooling and warming periods, associated with variability in sea ice coverage and productivity. The Neoglacial cooling was documented in various proxy reconstructions from the Nordic Seas (e.g., Jennings et al., 2002; Moros et al., 2004; Consolaro et al., 2018). However, there is growing evidence of shifts in environmental conditions in the Nordic Seas region in the Neoglacial, whose timings are in accordance with our record. An alkenone record from the Norwegian Sea revealed a significant drop in sea surface temperature at $2.7 \mathrm{cal} \mathrm{ka} \mathrm{BP}$ (Calvo et al., 2002). Risebrobakken et al. (2010) recorded a change in oceanographic conditions in the SW Barents Sea at ca. 2.5 cal ka BP. The episodes of reduced surface and subsurface salinity were recorded after $2.5 \mathrm{cal} \mathrm{kaBP}$, which was attributed to the expansion of coastal waters and the occurrence of more sea ice (Risebrobakken et al., 2010). Berben et al. (2017) recorded a shift at $\sim 2.7$ cal ka BP from the marginal ice zone to Arctic frontal conditions in the eastern Barents Sea. They observed a continuous cooling trend from $\sim 5.9$ to $2.7 \mathrm{cal} \mathrm{ka} \mathrm{BP}$, with increased seasonal sea ice with less open-water conditions, lower temperatures, and decreased AW influence, whereas after 2.7 cal ka BP the influence of AW was variable but generally generally increasing. The period was characterized by low insolation associated with surface cooling and enhanced formation of sea ice with reduced sea ice melt (Berben et al., 2017).

Moreover, our evidence of the presence of AW in Storfjorden during the Neoglacial supports previous suggestions that AW inflow during the late Holocene was strong enough to also reach the eastern coasts of Svalbard (e.g., Łacka et al., 2015). Episodic increases in the AW during the late Holocene were also observed in the northern Barents Sea (Duplessy et al., 2001; Lubinski et al., 2001), the eastern Barents Sea (Berben et al., 2014) and the Svalbard margin (Jernas et al., 2013; Werner et al., 2013). Sarnthein et al. (2003) postulated pulses of AW inflow to the western Barents Sea shelf at 2.2 and $1.6 \mathrm{cal}$ ka BP. According to Perner et al. (2015), the Neoglacial delivery of chilled AW to the Nordic Seas culminated between 2.3 and $1.4 \mathrm{cal} \mathrm{kaBP}$. These results are in accordance with the timing of major AW inflows revealed by our record.

\section{Conclusions}

The ST_1.5 multiproxy record revealed that the environmental variability in Storfjorden during the Neoglacial was controlled primarily by the interplay between AW, ArW and sea ice cover variability. The molecular record supports and complements sedimentary and microfossil records, which indicate that major changes in the environmental conditions in Storfjorden occurred at $\sim 2.7 \mathrm{cal}$ ka BP. The general cooling in the early phase of the Neoglacial initiated conditions for the formation of extensive sea ice cover. The latter part of the 
Neoglacial (after $\sim 2.7$ cal ka BP) was characterized by alternating short-term cooling and warming periods. Warming was associated with pulsed inflows of AW and sea ice melting, which may stimulate phytoplankton blooms and organic matter supply to the bottom. The cold phases were characterized by heavy and densely packed sea ice, resulting in limited productivity.

Moreover, the aDNA diatom record supports the conclusion that primary production took place continuously during the Neoglacial, regardless of the sea ice conditions. The early phase of the Neoglacial was characterized by the presence of diatom taxa associated with sea ice, whereas the present-day diatom assemblage is dominated by Chaetoceros spp., a taxa characteristic of open water.

The aDNA record of monothalamous foraminifera is in agreement with the microfossil record and revealed the timing of the major pulses of AW at 2.3 and $1.7 \mathrm{cal} \mathrm{kaBP}$. The AW inflow was marked by an increase in the percentage of sequences of monothalamous taxa associated with the presence of fresh phytodetritus. The monothalamous assemblage during cold intervals was less diverse and was dominated by monothalamous foraminifera known only from environmental sequencing.

Data availability. The abundance of fossil foraminifera and the number of foraminiferal and diatom aDNA sequences can be found in the Supplement (Tables S1, S2 and S3).

Supplement. The supplement related to this article is available online at: https://doi.org/10.5194/cp-16-487-2020-supplement.

Author contributions. MZ and JP designed the study. JP, MŁand MZ collected the sediment core. MŁand MK performed the sedimentological and micropaleontological analyses. JP performed the molecular analyses and prepared the paper with contributions from all coauthors.

Competing interests. The authors declare that they have no conflict of interest.

Acknowledgements. The authors would like to thank the Editor and the reviewers: Sarah Berben and two anonymous reviewers for constructive comments that helped to improve the paper.

Financial support. This research has been supported by the National Science Centre (grant nos. 2015/19/D/ST10/00244 and 2016/21/B/ST10/02308) and the Swiss National Science Foundation (grant no. 31003A_179125).
Review statement. This paper was edited by Bjørg Risebrobakken and reviewed by Sarah Berben and two anonymous referees.

\section{References}

Alve, E.: Benthic foraminiferal responses to absence of fresh phytodetritus: A two - year experiment, Mar. Micropaleontol., 76, 67-76, https://doi.org/10.1016/j.marmicro.2010.05.003, 2010.

Altschul, S. F., Gish, W., Miller, W., Myers, E. W., and Lipman, D. J.: Basic local alignment search tool, J. Mol. Biol. 215, 403-410, https://doi.org/10.1016/S0022-2836(05)80360-2, 1990.

Andersen, C., Koç, N., and Moros, M.: A highly unstable Holocene climate in the subpolar North Atlantic: evidence from diatoms, Quaternary Sci. Rev., 23, 2155-2166, https://doi.org/10.1016/j.quascirev.2004.08.004, 2004.

Årthun, M., Ingvaldsen, R. B., Smedsrud, L. H., and Schrum, C.: Dense water formation and circulation in the Barents Sea, Deep-Sea Res. Pt. I, 58, 801-817, https://doi.org/10.1016/j.dsr.2011.06.001, 2011.

Berben, S. M. P., Husum, K., Cabedo-Sanz, P., and Belt, S. T.: Holocene sub-centennial evolution of Atlantic water inflow and sea ice distribution in the western Barents Sea, Clim. Past, 10, 181-198, https://doi.org/10.5194/cp-10-181-2014, 2014.

Berben, S. M. P., Husum, K., Navarro-Rodriguez, A., Belt, T., and Aagard-Sørensen, S.: Semi-quantitative reconstruction of early to late Holocene spring and summer sea ice conditions in the northern Barents Sea, J. Quaternary Sci., 32, 587-603, https://doi.org/10.1002/jqs.2953, 2017.

Berger, A. L.: Long-term variations of daily insolation and quaternary climatic changes, J. Atmos. Sci., $\quad 35, \quad 2362-2367, \quad$ https://doi.org/10.1175/15200469(1978)035<2362:LTVODI>2.0.CO;2, 1978.

Blindheim, J. and Østerhus, S.: The Nordic Seas, main oceanographic features, in: The Nordic Seas: An integrated Perspective, edited by: Drange, H., Dokken, T., Furevik, T., Gerdes, R., and Berger, W., European Geophysical Union, Washington D.C., 1138, https://doi.org/10.1029/GM158, 2005.

Blott, S. J. and Pye, K.: GRADISTAT: a grain size distribution and statistics package for the analysis of unconsolidated sediments, Earth Surf. Proc. Land., 26, 1237-1248, https://doi.org/10.1002/esp.261, 2001.

Boere, A. C., Abbas, B., Rijpstra, W. I. C., Versteegh, G. J., Volkman, J. K., Sinninghe Damsté, J. S., and Coolen, M. J. L.: Late-Holocene succession of dinoflagellates in an Antarctic fjord using a multi-proxy approach: paleoenvironmental genomics, lipid biomarkers and palynomorphs, Geobiol., 7, 265281, https://doi.org/10.1111/j.1472-4669.2009.00202.x, 2009.

Cabedo-Sanz, P. and Belt, S. T.: Seasonal sea ice variability in eastern Fram Strait over the last 2000 years, Arktos, 2, 22, https://doi.org/10.1007/s41063-016-0023-2, 2016.

Consolaro, C., Rasmussen, T. L., and Panieri, G.: Palaeocoeanographic and environmental changes in the eastern Fram Strait during the last 14,000 years based on benthic and planktonic foraminifera, Mar. Micropaleontol., 139, 84-101, https://doi.org/10.1016/j.marmicro.2017.11.001, 2018.

Coolen, M. J. L., Saenz, J. P., Giosan, L., Trowbridge, N. Y., Dimitrov, P., Dimitrov, D., and Eglinton, T. I.: DNA and lipid molecular stratigraphic records of haptophyte succession in the Black 
Sea during the Holocene, Earth Planet. Sc. Lett., 284, 610-621, https://doi.org/10.1016/j.epsl.2009.05.029, 2009.

Coolen, M. J. L., Orsi, W. D., Balkema, C., Quince., C., Harris, K., Sylva, S. P., Filipova-Marinova, M., and Giosan, L.: Evolution of the plankton paleome in the Black Sea from the Deglacial to Anthropocene, P. Natl. Acad. Sci. USA, 10, 86098614, https://doi.org/10.1073/pnas.1219283110, 2013.

Calvo, E., Grimalt, J., and Jansen, E.: High resolution $\mathrm{U}_{37}^{K}$ sea surface temperature reconstruction in the Norwegian Sea during the Holocene, Quaternary Sci. Rev., 21, 1385-1394, https://doi.org/10.1016/S0277-3791(01)00096-8, 2002.

Cornelius, N. and Gooday, A. J.: "Live" (stained) deep-sea benthic foraminiferans in the western Weddell Sea: trends in abundance, diversity and taxonomic composition along a depth transect, Deep-Sea Res. Pt. II, 51, 1571-1602, https://doi.org/10.1016/j.dsr2.2004.06.024, 2004.

Cremer, H.: Distribution patterns of diatom surface sediment assemblages in the Laptev Sea (Arctic Ocean), Mar. Micropaleontol., 38, 39-67, https://doi.org/10.1016/S0377-8398(99)00037-7, 1999.

D’Andrea, W. J., Vaillencourt, D. A., Balascio, N. L., Werner, A., Roof, S. R., Retelle, M., and Bradley, R. S.: Mid Little Ice Age and unpredecented recent warmth in an 1800 year lake sediment record from Svalbard, Geology, 40, 1007-1010, https://doi.org/10.1130/G33365.1, 2012.

Dufresne, Y., Lejzerowicz, F., Apotheloz Perret-Gentil, L., Pawlowski, J., and Cordier, T.: SLIM: a flexible web application for the reproducible processing of environmental DNA metabarcoding data, BMC Bioinformatics, 20, 88, https://doi.org/10.1186/s12859-019-2663-2, 2019.

Duplessy, J. C., Ivanova, E., Murdmaa, I., Paterne, M., and Labeyrie, L.: Holocene paleoceanography of the northern Barents Sea and variations of the northward heat transport by the Atlantic Ocean, Boreas, 30, 2-16, https://doi.org/10.1111/j.15023885.2001.tb00984.x, 2001.

Forwick, M. and Vorren, T. O.: Late Weichselian and Holocene sedimentary environments and ice rafting in Isfjorden, Spitsbergen, Palaeogeogr. Palaeocl., 280, 258-274, https://doi.org/10.1016/j.palaeo.2009.06.026, 2009.

Forwick, M., Vorren, T. O., Hald, M., Korsun, S., Roh, Y., Vogt, C., and Yoo, K.-C.: Spatial and temporal influence of glaciers and rivers on the sedimentary environment in Sassenfjorden and Tempelfjorden, Spitsbergen, in: Geological Society, London, Special Publications, 344, 163-193, https://doi.org/10.1144/SP344.13, 2010.

Geyer, F., Fer, I., and Smedsrud, L. H.: Structure and forcing of the overflow at the Storfjorden sill and its connection to the Arctic coastal polynya in Storfjorden, Ocean Sci., 6, 401-411, https://doi.org/10.5194/os-6-401-2010, 2010.

Goldstein, S. T. and Alve, E.: Experimental assembly of foraminiferal communities from coastal propagule banks, Mar. Ecol.-Prog. Ser. 437, 1-11, https://doi.org/10.3354/meps09296, 2011.

Gooday, A. J.: Deep-sea benthic foraminiferal species which exploit phytodetritus: Characteristic features and controls on distribution, Mar. Micropaleontol., 22, 187-205, https://doi.org/10.1016/0377-8398(93)90043-W, 1993.
Gooday, A. J.: Organic-walled allogromiids: aspects of their occurrence, diversity and ecology in marine habitats, J. Foramin. Res., 32, 384-399, https://doi.org/10.2113/0320384, 2002.

Gooday, A. J., Bowser, S. S., Cedhagen, T., Cornelius, N., Hald, M., Korsun, S., and Pawłowski, J.: Monothalamous foraminiferans and gromiids (Protista) from western Svalbard: A preliminary survey, Mar. Biol. Res., 1, 290-312, https://doi.org/10.1080/17451000510019150, 2005.

Gooday, A. J., Anikeeva, O. V., and Pawlowski, J.: New genera and species of monothalamous Foraminifera from Bataclava and Kazach'ya Bays (Crimean Peninsula, Black Sea), Mar. Biodiv., 41, 481-494, https://doi.org/10.1007/s12526-010-0075-7, 2011.

Groot, D. E., Aagaard-Sørensen, S., and Husum, K.: Reconstruction of Atlantic water variability during the Holocene in the western Barents Sea, Clim. Past, 10, 51-62, https://doi.org/10.5194/cp10-51-2014, 2014.

Haarpainter, J., Gascard, J. C., and Haugan, P. M.: Ice production and brine formation in Storfjorden, Svalbard, J. Geophys. Res., 106, 14001-14013, https://doi.org/10.1029/1999JC000133, 2001.

Hald, M. and Steinsund, P. I.: Benthic foraminifera and carbonate dissolution in the surface sediments of the Barents and Kara Seas, Berichte zur Polarforschung, 212, 285-307, 1996.

Hansen, J., Hanken, N.-M., Nielsen, J. K., Nielsen, J. K., and Thomsen, E.: Late Pleistocene and Holocene distribution of Mytilus edulis in the Barents Sea region and its paleoclimatic implications, J. Biogeogr, 38, 1197-1212, https://doi.org/10.1111/j.1365-2699.2010.02473.x, 2011.

Herbert, P. D., Cywińska, A., Ball, S. L., and deWaard, J. R.: Biological identifications through DNA barcodes, Proc. Biol. Sci., 270, 313-321, https://doi.org/10.1098/rspb.2002.2218, 2003.

Hopkins, T. S.: The GIN Sea: A synthesis of its physicaloceanography and literature review, 1972-1985, Earth Sci. Rev., 30, 175318, https://doi.org/10.1016/0012-8252(91)90001-V, 1991.

Ikävalko, J.: Checklist of unicellular and invertebrate organisms within and closely associated with sea ice in the Arctic regions. MERI - Report Series of the Finnish Institute of Marine Research, 52, Helsinki, Finland, Finnish Institute of Marine Research, 2004

Ivanova, E., Murdmaa, I., de Vernal, A., Risebrobakken, B., Pevye, A., Brice, C., Seitkalieva, E., and Pisarev, S.: Postglacial paleoceanography and paleoenvironments in the northwestern Barents Sea, Quaternary Res., 92, 430-449, https://doi.org/10.1017/qua.2019.18, 2019.

Jennings, A. E., Knudsen, K. L., Hald, M., Hansen, C. V., and Andrews, J. T.: A mid-Holocene shift in Arctic sea-ice variability on the East Greenland Shelf, The Holocene, 12, 49-58, https://doi.org/10.1191/0959683602hl519rp, 2002.

Jennings, A. E., Weiner, N. J., Helgadottir, G., and Andrews, J. T.: Modern foraminiferal faunas of the southwestern to northern Iceland Shelf; oceanographic and environmental controls, J. Foramin. Res., 34, 180-207, https://doi.org/10.2113/34.3.180, 2004.

Jernas, P., Klitgaard Kristensen, D., Husum, K., Wilson, L., and Koç, N.: Palaeoenvironmental changes of the last two millennia on the western and northern Svalbard shelf, Boreas, 42, 236-255, https://doi.org/10.1111/j.1502-3885.2012.00293.x, 2013. 
Katsuki, K., Takahashi, K., Onodera, J., Jordan, R. W., and Suto, I.: Living diatoms in the vicinity of the North Pole, summer 2004, Micropaleontol., 55, 137-170, 2009.

Killworth, P. D.: Deep convection in the World Ocean, Rev. Geophys., 21, 1-26, https://doi.org/10.1029/RG021i001p00001, 1983.

Knies, J., Pathirana, I., Cabedo-Sanz, P., Banica, A., Fabian, K., Rasmussen, T. L., Forwick, M., and Belt, S.: Sea-ice dynamics in an Arctic coastal polynya during the past 6500 years, Arktos, 3, 1, https://doi.org/10.1007/s41063-016-0027-y, 2017.

Korsun, S. and Hald, M.: Modern benthic Foraminifera off Novaya Zemlya tidewater glaciers, Arct. Alp. Res., 30, 61-77, https://doi.org/10.1080/00040851.1998.12002876, 1998.

Korsun, S., Pogodina, I. A., Forman, S. L., and Lubinski, D. J.: Recent foraminifera in glaciomarine sediments from three arctic fjords of Novaja Zemlja and Svalbard, Polar Res., 14, 15-31, https://doi.org/10.1111/j.1751-8369.1995.tb00707.x, 1995.

Łącka, M., Zajączkowski, M., Forwick, M., and Szczuciński, W.: Late Weichselian and Holocene palaeoceanography of Storfjordrenna, southern Svalbard, Clim. Past, 11, 587-603, https://doi.org/10.5194/cp-11-587-2015, 2015.

Łącka, M., Cao, M., Rosell-Melé, A., Pawłowska, J., Kucharska, M., Forwick, M., and Zajączkowski, M.: Postglacial paleoceanography of the western Barents Sea: Implications for alkenone-based sea surface temperatures and primary productivity, Quaternary Sci. Rev., 224, 105937, https://doi.org/10.1016/j.quascirev.2019.105973, 2019.

Lejzerowicz, F., Esling, P., Majewski, W., Szczuciński, W., Decelle, J., Obadia, C., Martinez Arbizu, P., and Pawlowski, J.: Ancient DNA complements microfossil record in deep-sea subsurface sediments, Biol. Lett., 9, 20130283, https://doi.org/10.1098/rsbl.2013.0283, 2013.

Lecroq B., Lejzerowicz F., Bachar D., Christen R., Esling P., Baerlocher L., Østerås M., Frinelli L., and Pawlowski J.: Ultra-deep sequencing of foraminiferal microbarcodes unveils hidden richness in deep-sea sediments, P. Natl. Acad. Sci., 108, 1317713182, https://doi.org/10.1073/pnas.1018426108, 2011.

Loeng, H.: Features of the physical oceanographic conditions of the Barents Sea, Polar Res., 10, 5-18, https:/doi.org./10.3402/polar.v10i1.6723, 1991.

Lubinski, D. J., Polyak, L., and Forman, S. L.: Freshwater and Atlantic water inflows to the deep northern Barents and Kara seas since ca $13{ }^{14} \mathrm{C}$ ka: foraminifera and stable isotopes, Quaternary Sci. Rev., 20, 1851-1879, https://doi.org/10.1016/S02773791(01)00016-6, 2001.

Lydersen, C., Nøst, O., Lovell, P., McConell, B., Gammelsrød, T., Hunter, C., Fedak, M., and Kovacs, K.: Salinity and temperature structure of a freezing Arctic fjord - monitored by white whales (Delphinapterus leucas), Geophys. Res. Lett., 29, 2119, https://doi.org/10.1029/2002GL015462, 2002.

Mahé, F., Rognes T., Quince C., de Vargas, C., and Dunthorn, M.: Swarm: robust and fast clustering method for amplicon-based studies, Peer J., 2, e593, https://doi.org/10.7717/peerj.593, 2014.

Majewski, W., Pawłowski, J., and Zajączkowski, M.: Monothalamous foraminifera from West Spitsbergen fjords: a brief overview, Polish Polar Res., 26, 269-285, 2005.

Majewski, W., Szczuciński, W., and Zajączkowski, M.: Interactions of Arctic and Atlantic water-masses and associated environmental changes during the last millennium, Hornsund (SW
Svalbard), Boreas, 38, 529-544, https://doi.org/10.1111/j.15023885.2009.00091.x, 2009.

Mangerud, J., Bondevik, S., Gulliksen, S., Hufthammer, A. K., and Høseter, T.: Marine ${ }^{14} \mathrm{C}$ reservoir ages for 19 th century whales and mollusks from the North Atlantic, Quaternary Sci. Rev., 25, 3228-3245, https://doi.org/10.1016/j.quascirev.2006.03.010, 2006.

Martrat, B., Grimalt, J. O., Villanueva, J., van Kreveld, S., and Sarntheim, M.: Climatic dependence of the organic matter contributions in the north eastern Norwegian Sea over the last 15,000 years, Org. Geochem., 34, 1057-1070, https://doi.org/10.1016/S0146-6380(03)00084-6, 2003.

Müller, J., Werner, K., Stein, R., Fahl, K., Moros, M., and Jansen, E.: Holocene cooling culminates in sea ice oscillations in Fram Strait, Quaternary Sci. Rev., 47, 1-14, https://doi.org/10.1016/j.quascirev.2012.04.024, 2012.

Moros, M., Emeis, K., Risebrobakken, B., Snowball, I., Kuijpers, A., McManus, J., and Jansen, E.: Sea surface temperatures and ice rafting in the Holocene North Atlantic: climate influences on northern Europe and Greenland, Quaternary Sci. Rev., 23, $2113-$ 2126, https://doi.org/10.1016/j.quascirev.2004.08.003, 2004.

Nilsen, F., Cottier, F., Skogseth, R., and Mattson, S.: Fjord-shelf exchanges controlled by ice and brine production: The interannual variation of Atlantic Water in Isfjorden, Svalbard, Cont. Shelf Res., 28, 1838-1853, https://doi.org/10.1016/j.csr.2008.04.015, 2008.

Pawłowska, J., Lejzerowicz, F., Esling, P., Szczuciński, W., Zajączkowski, M., and Pawlowski, J.: Ancient DNA sheds new light on the Svalbard foraminiferal fossil record from the last millennium, Geobiology, 12, 277-288, https.://doi.org/10.1111/gbi.12087, 2014.

Pawłowska, J., Zajączkowski, M., Łącka, M., Lejzerowicz, F., Esling, P., and Pawlowski, J.: Palaeoceanographic changes in Hornsund Fjord (Spitsbergen, Svalbard) over the last millennium: new insights from ancient DNA, Clim. Past, 12, 1459-1472, https://doi.org/10.5194/cp-12-1459-2016, 2016.

Pawlowski, J., Holzmann, M., Berney, C., Fahrni, J., Cedhagen, T., and Bowser, S. S.: Phylogeny of alogromiid Foraminifera inferred from SSU rRNA gene sequences, J. Foramin. Res., 32, 334-343, https://doi.org/10.2113/0320334, 2002.

Pawlowski, J., Esling, P., Lejzerowicz, F., Cedhagen, T., and Wildings, T. A.: Environmental monitoring through protest nextgeneration sequencing metabarcoding: assessing the impact of fish farming on benthic foraminifera communities, Mol. Ecol. Res., 14, 1129-1140, https://doi.org/10.1111/1755-0998.12261, 2014.

Perner, K., Moros, M., Lloyd, J. M., Jansen, E., and Stein, R.: Mid to late Holocene strengthening of the East Greenland Current linked to warm subsurface Atlantic water, Quaternary Sci. Rev., 129, 296-307, https://doi.org/10.1016/j.quascirev.2015.10.007, 2015.

Piechura, J.: Dense bottom waters in Storfjord and Storfjordrenna, Oceanologia, 38, 285-292, 1996.

Polyakov, I. V., Pnyushkov, A. V., Alkire, M. B., Ashik, I. M., Baumann, T. M., Carmack, E. C., Goszczko, I., Guthrie, J., Ivanov, V. V., and Kanzow, T. T.: Greater role for Atlantic inflows on seaice loss in the Eurasian Basin of the Arctic Ocean, Science, 6335, 285-291, https://doi.org/10.1126/science.aai8204, 2017.

Quadfasel, D., Rudels, B., and Kurz, K.: Outflow of dense water from a Svalbard fjord into the Fram Strait, Deep-Sea Res., 
35, 1143-1150, https://doi.org/10.1016/0198-0149(88)90006-4, 1988.

Rasmussen, T. L. and Thomsen, E.: Brine formation in relation to climate changes and ice retreat during the last 15,000 years in Storfjorden, Svalbard, 76-78 N, Paleoceanography, 29, 911929, https://doi.org/10.1002/2014PA002643, 2014.

Rasmussen, T. L. and Thomsen, E.: Palaeoceanographic development in Storfjorden, Svalbard, during the deglaciation and Holocene: evidence from benthic foraminiferal records, Boreas, 44, 24-44, https://doi.org/10.1111/bor.12098, 2015.

Rasmussen, T. L., Forwick, M., and Mackensen, A.: Reconstruction of inflow of Atlantic Water to Isfjorden, Svalbard during the Holocene: Correlation to climate and seasonality, Mar. Micropaleontol., 94-95, 80-90, https://doi.org/10.1016/j.marmicro.2012.06.008, 2012.

Rasmussen, T. L., Thomsen, E., Skirbekk, K., ŚlubowskaWoldengen, M., Klitgaard Kristensen, D., and Koç, N.: Spatial and temporal distribution of Holocene temperature maxima in the northern Nordic seas: interplay of Atlantic-, Arcticand polar water masses, Quaternary Sci. Rev., 92, 280-291, https://doi.org/10.1016/j.quascirev.2013.10.034, 2014.

Reimer, P. J., Bard, E., Bayliss, A., Beck, J. W., Blackwell, P. G., Bronk Ramsey, C., and van der Plicht, J.: IntCal13 and Marine13 Radiocarbon Age Calibration Curves 0-50,000 Years Cal BP, Radiocarbon, 55, 1869-1887, https://doi.org/10.2458/azu_js_rc.55.16947, 2013.

Rigual-Hernández, A. S., Colmenero-Hidalgo, E., Martrat, B., Bárcena, M. A., de Vernal, A., Flores, J.A., Grimalt, J. O., Henry, M., and Lucchi, R. G.: Svalabrd ice-sheet decay after the Last Glacial Maximum: New insigths micropalaeontological and organic biomarker paleoceanographical reconstructions, Palaeogeogr. Palaeocl., 465, 225-236, https://doi.org/10.1016/j.palaeo.2016.10.034, 2017.

Risebrobakken, B., Moros, M., Ivanova, E. V., Chistyakova, N., and Rosenberg, R.: Climate and oceanographic variability in the SW Barents Sea during the Holocene, Holocene, 20, 609-612, https://doi.org/10.1177/0959683609356586, 2010.

Rognes, T., Flouri, T., Nichols, B., Quince, C., and Mahé, F.: VSEARCH: a versatile open source tool for metagenomics, Peer J., 4, e2584, https://doi.org/10.7717/peerj.2584, 2016.

Różańska, M., Poulin, M., and Gosselin, M.: Protist entrapment in newly formed sea ice in the Coastal Arctic Ocean, J. Mar. Syst., 74, 887-=901, https://doi.org/10.1016/j.jmarsys.2007.11.009, 2008.

Rudels, B., Korhonen, M., Schauer, U., Pisarev, S., Rabe, B., and Wisotzki, A.: Circulation and transformation of Atlantic water in the Eurasian Basin and the contribution of the Fram Strait inflow branch to the Arctic Ocean heat budget, Prog. Oceanogr., 132, 128-152, https://doi.org/10.1016/j.pocean.2014.04.003, 2015.

Sarnthein, M., Van Kreveld, S., Erlenkeuser, H., Grootes, P.M., Kucera, M., Pflaumann, U., and Schulz, M.: Centennial-tomillennial-scale periodicities of Holocene climate and sediment injections off the western Barents shelf, $75^{\circ} \mathrm{N}$, Boreas, 32, 447461, https://doi.org/10.1111/j.1502-3885.2003.tb01227.x, 2003.

Sabbattini, A., Morigi, C., Negri, A., and Gooday, A. J.: Distribution and biodiversity of stained Monothalamous foraminifera from Tempelfjord, Svalbard, J. Foramin. Res., 37, 93-106, htttps://doi.org/10.2113/gsjfr.37.2.93, 2007.
Sabbattini, A., Bonatto, S., Bianchelli, S., Pusceddu, A., Danovaro, R., and Negri A.: Foraminiferal assemblages and trophic state in coastal sediments of the Adriatic Sea, J. Mar. Syst., 105, 163174, https://doi.org/10.1016/j.jmarsys.2012.07.009, 2012.

Sabbattini, A., Nardelli M. P., Morigi C., and Negri, A.: Contribution of soft-shelled monothalamous taxa to foraminiferal assemblages in the Adriatic Sea, Acta Protozool., 52, 181-192, https://doi.org/10.4467/16890027AP.13.0016.1113, 2013.

Skogseth, R., Haugan, P. M., and Haarpaintner, J.: Ice and brine production in Storfjorden from four winters of satellite and in situ observations and modeling, J. Geophys. Res., 109, C10008, https://doi.org/10.1029/2004JC002384, 2004.

Skogseth, R., Haughan, P. M., and Jakobsson, M.: Watermass transformations in Storfjorden, Cont. Shelf Res., 25, 667-695, https://doi.org/10.1016/j.csr.2004.10.005, 2005.

Skogseth, R., Sandvik, A. D., and Asplin, L.: Wind and tidal forcing on the meso-scale circulation in Storfjorden, Svalbard, Cont. Shelf Res., 27, 208-227, https://doi.org/10.1016/j.csr.2006.10.001, 2007.

Stuiver, M. and Reimer, P. J.: Extended ${ }^{14} \mathrm{C}$ database and revised CALIB 3.0 ${ }^{14} \mathrm{C}$ age calibration program, Radiocarbon, 35, 215230, 1993.

Ślubowska-Woldengen, M., Rasmussen, T.L., Koç, N., KlitgaardKristensen, D., Nilsen, F., and Solheim, A.: Advection of Atlantic Water to the western and northern Svalbard shelf since 17,500 cal yr BP, Quaternary Sci. Rev., 26 463-478, https://doi.org/10.1016/j.quascirev.2006.09.009, 2007.

Telesiński, M. M., Przytarska, J. E., Sternal, B., Forwick, M., Szczuciński, W., Łącka, M., and Zajączkowski, M.: Palaeoceanographic evolution of the SW Svalbard shelf over the last 14000 years, Boreas, 47, 410-422, https://doi.org/10.1111/bor.12282, 2018.

Thomsen, P. F. and Willerslev, E.: Environmental DNA An emerging tool in conservation for monitoring past and present biodiversity, Biol. Conserv., 183, 4-18, https://doi.org/10.1016/j.biocon.2014.11.019, 2015.

Werner, K., Spielhagen, R. F., Bauch, D., Hass, H., Kandiano, E. S., and Zamelczyk, K.: Atlantic Water advection to the eastern Fram Strait - multiproxy evidence for late Holocene variability, Palaeogeogr. Palaeocl., 308, 264-276, https://doi.org/10.1016/j.palaeo.2011.05.030, 2011.

Werner, K., Spielhagen, R. F., Bauch, D., Hass, H. C., and Kandiano, E.: Atlantic Water advection versus sea-ice advances in the eastern Fram Strait during the last 9 ka: Multiproxy evidence for a two-phase Holocene, Paleoceanogr., 28, 283-295, https://doi.org/10.1002/palo.20028, 2013.

Winkelmann, D. and Knies, J.: Recent distribution and accumulation of organic carbon on the continental margin west off Spitsbergen, Geochem. Geophy. Geosys., 6, Q09012, https://doi.org/10.1029/2005GC000916, 2005.

Zimmermann, H. H., Stoof-Leichsenring, K. R., Kruse, S., Müller, J., Stein, R., Tiedemann, R., and Herzschuh, U.: Changes in the composition of marine and sea-ice diatoms derived from sedimentary ancient DNA of the eastern Fram Strait over the past 30,000 years, Ocean Sci. Discuss., https://doi.org/10.5194/os2019-113, in review, 2019. 